\title{
Paideusis
}

\section{Speaking in Our Own Voices: Plato's Protagoras and the Crisis of Education}

James Crooks

Volume 8, Number 1, 1994

URI: https://id.erudit.org/iderudit/1073261ar

DOI: https://doi.org/10.7202/1073261ar

See table of contents

Publisher(s)

Canadian Philosophy of Education Society

ISSN

0838-4517 (print)

1916-0348 (digital)

Explore this journal

Cite this article

Crooks, J. (1994). Speaking in Our Own Voices: Plato's Protagoras and the Crisis of Education. Paideusis, 8(1), 5-15. https://doi.org/10.7202/1073261ar 


\title{
Speaking in Our Own Voices: Plato's Protagoras and the Crisis of Education
}

\author{
James Crooks, Department of Philosophy, Bishop's University
}

In 1992, Bishop's University inaugurated an annual lecture in honour of F.R. Scott-philosopher, poet, constitutional expert, and distinguished alumnus. Our first speaker, Dr. Stuart Smith, presented a precis of his report on Canadian university education (Smith, 1991). The address contained-indeed, put on display -what looked for all the world like a surprising bit of optimism:

There is no crisis at the university. People are not howling with protest; they are not burning their degrees; there are no weak institutions; and there are no riots in the streets. Students are reasonably satisfied and professors wouldn't change jobs for anything in the world. (Smith, 1992, p. 3) ${ }^{1}$

Dr. Smith went on to make a strong case against the everyday varieties of "hell in a handbasket" griping to which most academics are given. This gentle scolding was acknowledged, accepted, and, I think, generally appreciated by those present at the talk. But I wonder if there were others like myself who thought the issue of crisis within the university, within education, and especially, perhaps, in relation to the positions of the teacher and the student, had been passed over too easily.

I wasn't about the challenge Smith at the time. What he had said about the widespread exaggeration of problems seemed, from a functional point of view, quite true. And, in any case, his performance that night had been ornamented by the kind of biting wit that makes one afraid of being embarrassed. Still, I was aware at the time of a vague conviction that there was a kind of crisis worth considering in relation to our universities and the reason that it went undetected in Smith's research was that it was largely, if not entirely, resistant to the techniques he had used to gather information.

In what follows, I am concerned to accomplish two things. First, I sketch briefly what I take to be the real nature of crisis in education-its perennial crisis, if I might put it in that way, for a certain kind of crisis is education's constant companion. Second, I will comment on the specific responsibility of academics (teachers, researchers, and students) in relation to this crisis. In both cases, I shall be guided by some of Plato's texts. No one, it seems to me, has been more astute than he in recognizing the n'stacles we face in the acquisition of knowledge, nor more profound in responding to them.

\section{The Extraneous Voice}

Our word "crisis" comes from the Greek "krisis"-decision or turning point. Perhaps we might begin, in our attempt to recover for this term a force beyond that accorded to it by Smith, with the reminder that Plato's philosophy of education, so fundamental to the Western conception of learning, is really nothing but an analysis of crisis in the original sense. Consistently, the dialogues connect the process of acquiring genuine insight with what we might call gestures of decision, reversal, or turning around. The Socratic elenchus (examination, or refutation), for example, prods us in the direction of adequate 
understanding by deciding the viability of one or more hypotheses on a given matter. Socratic irony reverses the explicit meaning of statements, arguments, even entire inquiries, with a view to disclosing a wider scope of relations between language and learning. In works of the early-middle and middle period (Meno, Phaedo, and Phaedrus, to name three), Plato connects knowledge and recollection (a kind of intellectual turn, or return). And in the Republic, of course, he describes the whole art of education as that of "turning the soul" (Plato, 1961a, 518c-d).

Beyond the inscription of such gestures in his own procedure, but clearly also in service to the same pedagogical ends, Plato calls on us as readers, and as students, to decide how we ourselves will think and philosophize. Accordingly, a good number of the dialogues may also be read as documents of a rather profound struggle: between Socratism and the poetic tradition, for example, or between reflective inquiry and sophism. In other words, Plato's discursive "turns" are often mounted explicitly in opposition to one or more unacceptable alternatives. We are exhorted, in a good number of places, to decide against the authority of poets or sophists, to pursue our educational goals by turning away from one or more forms of ersatz knowledge.

One of the texts in which this oppositional structure is deployed most effectively is the Protagoras, a work of Plato's early or early-middle period. It recounts a more or less friendly war of words between Socrates and the famous sophist. The battle itself surmounts the structure of elenchus which circumscribes Socrates' encounters with less experienced interlocutors in the early dialogues. It is, in effect, a war of discourses or methods: the question and answer of philosophy versus the ornate language of the professional rhetorician.

I will frame what I take to be the genuine question of crisis in education in reference first to a volley fired in the middle of this war. At $347 \mathrm{~b}$, Socrates breaks his own extended interpretation of a poem by Simonides with the following plea for the resumption of what he takes to be the true philosophic discourse of question and answer:

Then. . I leave it to Protagoras to do whichever pleases him. But if he is agreeable, I suggest we leave the subject of songs and poems, for I should be glad to reach a conclusion, Protagoras, in a joint investigation with you, on the matters about which I asked you at the beginning [concerning virtue and its teachability]. Conversation about poetry reminds me too much of the wine parties of second-rate and commonplace people. Such men, being too uneducated to entertain themselves as they drink by using their own voices and conversational resources, put up the price of female musicians, paying well for the hire of an extraneous voice-that of the pipe-and find their entertainment in its warblings. But where the drinkers are men of worth and culture, you will find no girls piping, or dancing, or harping. They are quite capable of enjoying their own company without such frivolous nonsense, using their own voices in sober discussion and each taking his turn to speak or listen-even if the drinking is really heavy. In the same way, gatherings like our own, if they consist of men such as most of us claim to be, call for no extraneous voices-not even of poets. No one can interrogate poets about what they say, and most often when they are introduced into the discussion some say the poet's meaning is one thing and some another, for the topic is one upon which no one can produce a conclusive argument. The best people avoid such discussions, and entertain each other from their own resources, 
testing one another's mettle in what they have to say themselves. (Plato, $1961 b, 347 b-348 a)^{2}$

One is struck here first, perhaps, by the almost aggressive sexist or elitist dimension of Socrates' language. The modern ear has attuned itself to such dissonances. But listen further. There is also something in this passage, pertinent to our question about the appropriate sense of crisis, and so, to what we might call the scene of education, which surmounts social or political differences. Plato here designates persons of "worth and culture" (by which he means not the well-born but the authentically learned) as those who speak "using their own voices." The uneducated, on the other hand, are said to give their proxy, in matters calling for serious conversation, to an "extraneous voice," at times as frivolous as the "warblings" of popular music, at times considerably more respectable, as in the case of poets.

We might suspect, with a view to this distinction, that what is decided in the process of education is a certain relation to these voices or discourses. But if that is so, then the process of education, above all, what we call higher education, and the institutions set up to safeguard that process, have been, are at present, and ought always to be in crisis, both i) in the sense that their original mandate is to turn us away from extraneous voices, and ii) in the sense that this turning away is itself a struggle which might be lost.

This is my thesis. But I am already ahead of myself. What does Plato mean by extraneous voices? In what sense does it fall to the educator to wrestle with these voices or discourses? What are the gestures appropriate to this struggle? And how do they give us our own voice in things?

The extraneous voices to which Plato has Socrates refer at $347 \mathrm{~b}$ appear to designate a group of discourses which have at least three things in common. First, and most importantly, the extraneous voice substitutes for (and so also displaces) genuine conversation.

Conversation about poetry reminds me too much of the wine parties of second-rate and commonplace people. Such men, being too uneducated to entertain themselves as they drink by using their own voices and conversational resources, put up the price of female musicians, paying well for the hire of an extraneous voice. ...

For the early Plato, where dialogue, genuine conversation, and moral education are inseparable, such a substitution is disastrous. It defers indefinitely the turn about which the Socratic elenchus is designed to produce, and so, derails the real progress of learning. If the pronouncements of poets, sophists, or other sources of conventional wisdom are taken over unreflectively and given out as our own knowledge, then legitimate inquiry is soon reduced to a parody of itself: dutiful recitation masquerading as meaningful exchange. We become incapable of a real encounter of the limits of our understanding, and so, of real intellectual growth, because the understanding we cleave to is not our own.

The second mark of the extraneous voice or discourse, again following Socrates at $347 \mathrm{~b}$, is absence, or perhaps more precisely, the unavailability of the original speaker for cross-examination.

In the same way gatherings like our own, if they consist of men such as most of us claim to be, call for no extraneous voices-not even of poets. No one can interrogate poets about what they say... 
The fact that poets, sophists, and other sources of conventional wisdom stand outside the realm of dialogue and interrogation, either because they are long since dead (Homer, Hesiod, Thales) or living, but in some other place, is often mistaken for a capacity to withstand such things. Words, maxims, codes, and so forth, passed from one generation to another, disseminated through students and disciples, acquire, in the passage or dissemination itself, a certain value and authority. This means, effectively, that in the repetition of what a poet or a sophist says, we express also a history of acceptance and recognition. The speech of the original speaker, often long since absent and unavailable, confronts us in such situations as a kind of perennial insight, time tested, as it were: a state of affairs which makes the displacement of genuine conversation I spoke of moments ago all the more tempting.

The third mark of the extraneous voice or discourse is abstraction. Here we might borrow Kierkegaard's image of the world of ideas as a kind of gigantic "bargain basement."3 As regards what is said by the extraneous voice, one size fits all.

No one can interrogate poets about what they say, and most often when they are introduced into the discussion some say the poet's meaning is one thing and some another, for the topic is one upon which no one can produce a conclusive argument.

Such hermeneutical undecidability is related closely to the theme of absence we spoke of just now. The processes of repetition and dissemination by virtue of which the words of poets, sophists, and others unavailable for interrogation first acquire value and authority, also entail de-contextualization. This, in fact, is the price of discursive mobility. Words, maxims, codes, and so on, which are presented to us as having universal applicability, belong to no situation in particular. They are quite indifferent to the unique resonances of a given conversation or inquiry, in the course of which we always speak about some matter by speaking to unique individuals with peculiar histories and commitments, biases and ideas.

So much for the properties of the extraneous voice. In what sense does it fall to the educator to wrestle with these voices or discourses? Responding to this question, I should like to make Plato's Socrates, especially as portrayed in the Protagoras, a kind of paradigm against which we might take the measure of our own responsibilities. I shall return here, as well, to Smith's address; not in its specifics but as a project, a discourse.

If one looks at Plato's dialogues generally, keeping in view the commentary on the relation of speech and education cited earlier, one sees that Socrates positions himself as a teacher between two species of extraneous voice. The first speaks, as it were, from below, which is to say, from the mouths of the young and inexperienced (Lysis, Charmides, Meno's slave boy, Phaedrus, Glaucon and Adeimantus) or the philosophically naive (Crito, Nicias and Laches, Euthyphro). Persons of this kind invariably make their entrance in Plato's drama as unwitting mouthpieces of cultural or conventional wisdom. What they present as knowledge, in response to Socrates' questions, is almost always some kind of abstract definition, taken either directly from an absent authority (for example, a poet or a sophist) or from what might be called the consensus of opinion (the absent authority par excellence). Socratic elenchus 
responds to this kind of presentation, this thinking by proxy, by attempting to convert it into its opposite or turn it around. In the process of examination and refutation, the interlocutor is brought to realize that neither the words of an authority nor the consensus of opinion can substitute for or displace her/his responsibility for speaking to and with others about those matters which address us as important. ${ }^{4}$

The other species of extraneous voice to which we can point in Plato's work speaks, as it were, from above, which is to say, from the mouths of those charged with the task of navigating on the educational voyage and credited with the ability to do so (in this context, we might think first of Protagoras, but also Gorgias, Thrasymachus, Polus, Euthydemus and Dionysodorus). From the standpoint of pedagogy, the voice or discourse of professional educatorssophists-represents a more complex and difficult problem. It is not simply the naive repetition of cultural or conventional wisdom. On the contrary, sophistic discourse reduces education, in advance, to the acquisition of a certain cleverness, a style of speaking, in which the confusion of knowledge with the possession and cultivation of opinions-the same confusion Socrates tries to untangle in his naive interlocutors-is celebrated and entrenched. Responding to this fortification, something more than the examination and refutation of individual positions is needed. Accordingly, Plato's struggle with sophistry aims at a conversion of discourse itself. In the Protagoras and elsewhere, he makes it evident that what falls to the genuine thinker, to the genuine teacher, is to enkindle a crisis, a turn-around, relating to language as such. I shall say something further regarding the substance of this turn in a few moments.

But now, how relevant is the pedagogical position of Plato's Socrates to those of us who find ourselves teaching and working in the university at present? (I am thinking here especially, it should be admitted, of teaching and working in the humanities). There are differences, obviously. For better or worse, we no longer accord much authority to what poets say. And for the discourse of sophistry, we might be well advised to substitute that of the political bureaucracy. Beyond such things, however, our position is fundamentally the same. Like Plato's Socrates, our workplace is defined, both from below and from above, by a struggle with the extraneous voice.

From below, our students, for the most part, still come to the university functioning as mouthpieces of conventional wisdom. As a teacher, I have been addressed on countless occasions now by an extraneous voice which we might call "bourgeois relativism." It speaks to me through some earnest soul whenever one of philosophy's fundamental questions is put up for discussion (such as "What is truth?" "You can't answer that. It's subjective." "What is justice?" "You can't answer that. What's just for me may not be just for you.") and it conforms nicely to the discursive parameters we extracted from the Protagoras earlier.

From above, we are extorted, more and more forcefully in tough economic times, to translate our educational mission into the discourses of business administration and political lobby. Courses of study become academic products, and the relation of the university to the world-at-large is described in the language of the marketplace by those "in the know." It would be wrong to presume that this way of thinking and speaking constitutes a realistic or pragmatic alternative to the voice of bourgeois relativism we hear so often in intro- 
ductory discussions with our students. On the contrary, the discourses of the political bureaucracy can take hold of the university and dominate it only if the consensus of opinion, expressed unwittingly by the naive student, is accepted and promoted as the thing that really matters.

On this note, perhaps, we ought to listen again to the words of the Smith report which I cited at the beginning. For it seems to me that what speaks in them is a kind of modern sophism, the extraneous voice of the political bureaucracy. It is predicated on a valorization of opinion, the origin of which is unavailable for interrogation, abstract and uniform in its response to all problems and situations, and so, in the end, hostile to genuine dialogue:

There is no crisis at the university. People are not howling with protest; they are not burning their degrees; there are no weak institutions; and there are no riots in the streets. Students are reasonably satisfied and professors wouldn't change jobs for anything in the world.

With a view to what I have said concerning the structure of extraneous voices in general, and with respect to sophism (ancient or modern) in particular, I suggest that Smith's remarks and the projects they represent are problematic in a double sense. On the one hand, they presume that the real judgment concerning the question of crisis at the university may be handed down by the court of opinion (polls and interviews reveal that people "are not howling with protest. . .are not burning their degrees"). If, however, the university is the home of an intellectual encounter in which the rulings of such a court are shown to be irrelevant, if the court of opinion represents one of those extraneous voices with which we as educators ought always to be at odds, then how important are its pronouncements for us-one way or the other? On the other hand, the whole discussion diverts our attention from the authentic challenge we confront as teachers and researchers, whether in Canada in the 1990s or in some other place and time-that of finding ways to enkindle crisis in the original sense, of dislodging ourselves and our students from the extraneous voices which crowd around us from above and below, of really speaking to and with one another, of speaking in our own voices. I should like to ponder, again with one eye on Plato's Protagoras, what might be necessary for that.

\section{Our Own Voices}

It is one thing to point fingers at Stuart Smith (or someone else), but quite another to propose a positive thesis. The detection of extraneous voices is a sport of choice in the post-modern age. But what are the marks of a discourse which is spoken in our own voices? What understanding of language is appropriate to the scene of education? We said before that our word "crisis," taken in its original sense, means decision or turning point, that Plato's philosophy of education is really nothing but an extended analysis of this turn, and that, in a good number of places (the Protagoras included), this analysis is posed explicitly in opposition to one or more unacceptable alternatives, one or more extraneous voices. According to this argument, however, the discursive gestures which define the extraneous voice ought to point us, at the same time, in the direction of a proper relation to language. To turn away from inappropriate modes of speech is to turn toward what is appropriate. Let us consider again the Protagoras, our test case, to see if this is so. 
As a dramatic structure, the dialogue resembles a four-act play. After the curtain rises, the scene is set (309a-328d): Socrates recounts for an unidentified friend the circumstances that led to his meeting with Protagoras, names those present, and so on. A point of conflict emerges: Socrates expresses his wellknown doubts concerning the teachability of virtue, eliciting from Protagoras an eloquent defence of his trade. Acts II through IV (in keeping with the metaphor) recount Socrates' attempt to dismantle this defence, to turn Protagoras and the others present away from sophistic discourse (the long and ornate speech) and toward question and answer. Within this attempt, one can discern three distinct gestures or performances of the discursive turn.

Act II (328d-338e) features the elenchus. Socrates questions the sophist closely on a "small point" (329b-c), ambiguous in his speech, concerning the unity of the virtues-to wit, whether the virtues (justice, temperance, piety, and so forth) are parts of virtue ". . . as the parts of a face are parts-mouth, nose, eyes and ears-or like parts of a piece of gold, which do not differ from one another or from the whole except in size" (329d). Protagoras, defending the first of these options, is eventually refuted. We need not rehearse the arguments. At the macro-textual level of the relation of discourses, what bears notice is that this engagement, taken as a whole, acts as a kind of wedge or point of re-entry into Protagoras' impressive speech defending the teachability of virtue (the climax of Act I, 320c-328d). Socrates begins with a question which is admittedly of minor importance within the speech itself. But the fact that he is able to fluster Protagoras so effectively in examination of it causes the matters Protagoras had sought to put to rest to rise up before us again as questionable.

Act III (338e-348b) - for our purposes a more complicated affair-features what might be described best as a parody of sophistic discourse. It begins with a role-reversal. Protagoras tries to regain the upper hand in the argument by playing the questioner. And he tries to corral Socrates the interpretation of poetry, an area in which he has expertise. At the centre of the discussion are two verses by the poet Simonides:

Hard it is on the one hand to become

A good man truly, hands and feet and mind

Foursquare, wrought without blame.

Nor do I count as sure the oft-quoted word

Of Pittacus, though wise indeed he was

Who spoke it. To be noble, said the sage,

Is hard. (339b-c)

Protagoras asks Socrates whether or not these statements are consistent. He replies, without hesitation, that they are. Then, Protagoras springs a trap of sorts:

How can a man be thought consistent when he says both these things? First he lays it down himself that it is hard for a man to become truly good; then when he is a little further on in the poem he forgets. He finds fault with Pittacus, who said the same thing as he did himself, that it is hard to be noble, and refuses to accept it from him. . . Either his first or his second statement is wrong. (339d)

In response to this indictment, Socrates gives a long speech: dense, pedan- 
tic, and fast and loose in its interpretation of Simonides ${ }^{5}$ It is obviously a joke at the expense of sophistry, designed, like the elenchtic episode, to undermine Protagoras' original speech. But even in jest (indeed, perhaps especially there), Plato inscribes a kind of discursive turn which is crucial to the impact of the dialogue as a whole. Socrates defends Simonides by arguing that the poet's real aim, in the verses we repeated just now, is to distinguish becoming virtuous, or good, or noble from being so. The former, spoken about by Simonides in the first verse, is difficult: the pursuit of virtue requires constant exertion, rising up before us new each day as our task. The latter, spoken about in the maxim ascribed to Pittacus in the second verse, is impossible: for it would require that virtue be something we could appropriate once and for all, the way we purchase things at the market. This distinction, obviously not anticipated by Protagoras in springing his "trap," is itself an indictment of sophism, the operative presumption of which is clearly that virtue is marketable, that it can be passed like a commodity from person to person and, so, bought and sold. The entire line of analysis is eventually broken off by Socrates himself with the commentary on "the wine parties of second-rate and commonplace people" and "extraneous voices" which we looked at in the first part of this paper (347b). Whereupon Protagoras, weary of Socratic sophistry, agrees, somewhat reluctantly, to resume the role of respondent. However, Socrates' parody of sophistry has, in its very excess, disclosed both the illegitimacy of such speeches in serious inquiry and (in its central distinction between being and becoming virtuous) the real point of difference between sophists and philosophers.

Act IV (348b-362a), the question and answer which comes on the heels of Socrates' hermeneutical adventures, follows the conversation to its end. Here, as in Act II, there is an elenchus. As before, its principal object is the contention that individual virtues are largely independent in nature. After some preliminary sparring, the interlocutors turn to the subject of courage, a virtue which Protagoras claims may be possessed with or without justice, temperance, piety, knowledge, and the others (that is, independently of them). Socrates attacks this thesis vigorously. But as the dialogue closes, neither he nor Protagoras is moved to concede. Again, the series of propositions which leads to this impasse is secondary. At the macro-textual level, what counts are the implications of each position for the central question of the teachability of virtue, the real frame of the entire discussion. These are spelled out in Socrates' final speech-a lovely bit of irony which traces crisis into clearer focus:

It seems to me that the present outcome of our talk is pointing at us, like a human adversary, the finger of accusation and scorn. If it had a voice, it would say, "What an absurd pair you are, Socrates and Protagoras. One of you, having said at the beginning that virtue is not teachable, now is bent upon contradicting himself by trying to demonstrate that everything is knowledge-justice, temperance, and courage alike-which is the best way to prove that virtue is teachable. If virtue were something other than knowledge, as Protagoras tried to prove, obviously it could not be taught. But if it turns out to be, as a single whole, knowledge-which is what you are urging, Socrates-then it will be most surprising if it cannot be taught. Protagoras, on the other hand, who at the beginning supposed it to be teachable, now on the contrary seems bent on showing that it is almost anything rather than knowledge, and this would make it least likely to be teachable." (360a-361c) 
Two things get said here. On the one hand, Socrates recognizes explicitly the fact that the course of the arguments he has followed with Protagoras has produced a reversal, a complete turn around, with respect to the question of virtue's teachability. The thesis that the virtues may be cultivated independently, so that something like courage might be had apart from knowledge or wisdom (Protagoras' view) actually bodes ill for sophistry. After all, every teaching is the communication of some knowledge. The thesis that the virtues are inseparable, implied, at least, by Socrates' attacks on Protagoras, actually renders the possibility of their being taught far more likely. If courage, for example, is a kind of knowledge or wisdom, then it may be communicable.

At first glance, this switch seems merely comical ("What an absurd pair you are, Socrates and Protagoras'), an anticlimax. Both men seem to have refuted themselves unwittingly. Yet, and this would be the second thing, if we remember and accept the distinction between being and becoming virtuous, the sincere heart of Socrates' parody of sophistry, we are led to see that the joke is on Protagoras alone. For if we concern ourselves with becoming rather than being virtuous, then the teaching of virtue, the process which guides the becoming, can be seen to correspond exactly to the Socratic elenchus.

We said before that Plato's struggle with sophistry aims at a conversion of discourse itself. Socrates' final volley completes this turn. In the end (Act IV especially), he secures from Protagoras an argument against his own procedure. What rises up before us in its place is the task of becoming virtuous, of becoming what we are, through philosophic dialogue.

Now, draw back. How relevant are the gestures of this ancient thinking to the understanding of language appropriate to the scene of education? What does Plato's enkindling of crisis, his multiple turns away from sophistry, away from extraneous voices, tell us about speaking for ourselves? About speaking in our own voices?

It is tempting, especially for modern readers, to reduce the conflict between Socrates and the sophists throughout the dialogues to a kind of methodological dispute. Such a reduction, however, conceals something essential: namely, that all of Plato's discursive turns against or away from unacceptable alternatives are designed to give us the matters about which we speak in the right sort of way, or more specifically, to put the matters about which we speak in our future (that is, in front of us) so that they address us as our possibilities. What really happens in the crisis of the elenchus? In parody or in Socratic irony? Some matter for which sophistry or consensus had brokered a settlement rises up in rebellion and presents itself as questionable. At the end of the Protagoras, Socrates says explicitly:

It seems to me that the present outcome of our talk [about the attempt to settle the matter of virtue and its teachability] is pointing at us, like a human adversary, the finger of accusation and scom. If it had a voice, it would say, "What an absurd pair you are, Socrates and Protagoras."

We ought to take this imagery seriously. The purpose of Plato's crises in the Protagoras, of all crisis in education, is to animate the body of knowledge. Clearly, this is an affair as urgent for us in the 1990s as for the Greeks of the 4th century. As teachers, researchers, and students at the university, our responsibility is to create a place in which it is possible to see the matters that concern 
us "pointing at us," addressing us "like a human adversary." Addressing us. That means speaking to where we find ourselves in the world.

If and when we are thus addressed, it seems to me that we enter into a privileged understanding of language. For in those moments, we see that to speak is to respond to the challenge of the things that matter and to make ourselves responsible. In those moments, we come to the body of knowledge out of our own condition, knowing becomes for us an authentic affair-a way of living, we might say-which cannot possibly be commodified, bartered, sold, or in any way rendered extraneous, because, as a response, it is itself an orchestration, a voicing, of circumstances that are essentially ours. Our responses may or may not reshape the questions which elicit them. We may or may not become academic celebrities. No matter. They are, nevertheless, absolutely decisive, absolutely definitive, for us who teach and study. In responding to the address that arrives with the crisis of education, we cultivate what is truly ours, we speak in our own voices.

These reflections were born out of a certain feeling of unease occasioned by Smith's declaration that is no crisis at the university-words that ironically were intended to reassure. It seems to me that the truth of his claim entails one of two things. Either our talk about the present and future of the university has been co-opted by the extraneous voice of the political bureaucracy (I take Smith's document as quite representative of current discussion of such things), in which case we should do what we can to turn things around, or there really is no crisis at the university, in which case its original mandate has been forgotten entirely.

\section{Notes}

1The title of Smith's lecture was "A Canadian University in the 1990s." It was delivered at Bishop's University, November 17, 1992. Smith's full report was commissioned by the Association of Universities and Colleges of Canada.

${ }^{2}$ All subsequent citations from the Protagoras are taken from the Hamilton Cairns edition, (see Notes, Plato, 1961b). Henceforth, only standardized line numbers will be provided as reference.

${ }^{3}$ See Kierkekgaard's Fear and Trembling, p. 41.

${ }^{4}$ Readers of Plato will perhaps have had this experience: at the end of the text, of the dialogue, a real conversation stretches out in front of us which we find ourselves far better able to begin. This is the effect of Socratic teaching-indeed, of all good teaching.

${ }^{5}$ See, for example, Vlastos' commentary on this text in Socrates: Ironist and Moral Philosopher, pp. 135-7.

\section{References}

Kierkegaard, Soren (1985). Fear and Trembling. Translated by Alastair Hannay. London: Penguin Books.

Plato (1961a). Republic. The Collected Dialogues of Plato. Edited by Edith Hamilton and Huntington Cairns. Princeton, NJ: Princeton University Press, pp. 575-844. 
Plato (1961b). Protagoras. The Collected Dialogues of Plato. Edited by Edith Hamilton and Huntington Cairns. Princeton, NJ: Princeton University Press, pp. 308-352.

Smith, Stuart (1991). Report: Commission of Inquiry on Canadian University Education. Copies of the report may be obtained from the Publications Office of the Association of Universities and Colleges of Canada, 151 Slater Street, Ottawa, ON K1P 5N1.

Smith, Stuart (1992). "A Canadian University in the 1990s." Copies of the address may be obtained from the Registrar's Office, Bishop's University, Lennoxville, PQ J1M $1 Z 7$.

Vlastos, Gregory (1991). Socrates: Ironist and Moral Philosopher. Ithaca, NY: Cornell University Press. 